\title{
THE INFLUENCE OF POWTOON MEDIA IN TEACHING LISTENING
}

\author{
Gerry Heryanto ${ }^{1}$, Silpia Rahayu ${ }^{2}$ \\ IKIP Siliwangi \\ ${ }^{1}$ gerry.heryanto@ studentikipsiliwangi.ac.id, ${ }^{2}$ silpiarahayu@ikipsiliwangi.ac.id
}

\begin{abstract}
The development of technology and information greatly affect the use of media as a tool in teaching process. The role of the teacher here is not just to convey the material, but is expected to be able to utilize the technology to support teaching and learning activities, the selection of appropriate learning media is very influential on the achievement of educational goals. The purpose of this study was to determine how the influence of the use of powtoon media in the process of learning listening in eighth grade students at one of the junior high schools in Cimahi. The research method used is descriptive qualitative. Subjects in this research were eighth grade students with a total 25 students consisting of 10 male students and 15 female students. The instrument used was a questionnaire with 10 statement items, consisting of 5 positive statements and 5 negative statements. The results of this study indicate that the influence of the use of powtoon as a media in learning listening of eighth grade students at one of junior high schools in Cimahi is categorized very well with an average percentage of $100 \%$.
\end{abstract}

Keywords: Case Study, Listening, Powtoon Media

\section{INTRODUCTION}

The 2013 curriculum paradigm shift regarding learning patterns that were originally based on a single tool has now become multimedia-based learning. As for what is meant by multimedia is a media that can directly involve student experience with involving all the senses. Along with the times, technology and information are very influential on the use of learning media. In this case the teacher is required to be able to utilize the technology, as a tool in learning. One type of technology-based learning media is Powtoon. According to (Nanni, 2015) Powtoon is an online software-based animation service that allows users to more easily understand making short videos by including images, music, writing, and other animation effects. Powtoon has a variety of features that are complete choices that can make it easier for teachers to plan video material to be produced (Günaydın \& Karamete, 2016) with a more attractive appearance the use of powtoon media can create a pleasant and not boring learning atmosphere so students are more interested in participating in learning activities. Based on (One, 2017) the advantages of powtoon that are include all aspect of senses, practically, and more variety also motivated students in the teaching process. Something can be said that learning is when there is interaction between the teacher and students, the process of giving and receiving information in the form of science by utilizing available resources to achieve learning objectives. This is in line with the statement of (Suhara, 2014) that learning is interpreted as a process of cooperation between teachers and students in utilizing all the potentials and existing sources of potential originating from within students, as well as potentials that exist outside of students as an effort to achieve learning objectives.

Based on the 2013 curriculum, English learning at the VIII grade junior high school is divided into four language skills. The role of listening is very important to be applied in daily life or 
past events or events that are happening. To be able to understand and produce these types of texts, good listening skills are needed, thus language skills become one of the skills that students must master, especially in English lessons. Basically listening is an activity of obtaining information and knowledge and getting good communication goals with others. Based on (Hadian, 2015) listening is a language activity that is often done.

The problem raised by researcher in this scientific work is learning to listen to past events or events in the past that have already occurred. In general, past tense is a text that describes a series of events or events that have occurred in the past can occur (yesterday, last week, or last month, even last year) can be mentioned specifically. Difficulties that might later be faced by students in learning are in determining the words, how to pronunciation of the words they have just heard, then it is difficult in pouring ideas into a writing. The low abilities of students in vocabulary is caused by several factors, one of which students tend not to have an interest in learning, so they get bored quickly. So on the basis of the above explanation the researcher formulated the research with the title "The Influence of Media Powtoon In Learning Listening".

\section{METHOD}

The method used in this research is descriptive qualitative, with the subject of all eighth grade students in one junior high school in Cimahi, totaling 25 students. While the research instrument used was a questionnaire that was distributed to all students. After obtaining the data, the researcher then describe the data into writing and tables so that researcher more easily know the effect of using media powtoon in learning to listen. In this research, the scale used in the questionnaire is the Guttman scale. According to (Sugiyono, 2017) this type of scale will get a firm answer which is "yes or no". The data obtained can be two alternative interval data that is "agree" and "disagree". The answer can be made the highest score with one and the lowest score with zero. If the scores are converted into a percentage, it can logically be translated for agreed answers $1=1 \times 100 \%$, and disagree is given a score of $0=0 \times 0 \%=0 \%$.

\section{RESULTS AND DISCUSSION}

\section{Results}

To find out the description of the influence of powtoon media in learning to write explanatory texts on 8th grade junior high school students in one junior high school in cimahi, descriptive analysis was used based on responses to the statements in the questionnaire. The following is presented the acquisition of questionnaire data that has been filled out by students.

Table 1. Result of Questionnaires

\begin{tabular}{cccc}
\hline Positive Statements & Frequency & Percentage & Score \\
& & & \\
\hline Statement 1 & 25 & $100 \%$ & Very good \\
\hline Statement 2 & 25 & $100 \%$ & Very good \\
\hline Statement 6 & 25 & $100 \%$ & Very good \\
\hline Statement 7 & 25 & $100 \%$ & Very good \\
\hline Statement 8 & 25 & $100 \%$ & Very good \\
\hline Statement 9 & 25 & $100 \%$ & Very good \\
\hline Negative Statements & 25 & $100 \%$ & Very good \\
\hline Statement 3 & 25 & $100 \%$ & Very good \\
\hline Statement 4 & 25 & $100 \%$ & Very good
\end{tabular}




\begin{tabular}{cccc} 
Statement 5 & 25 & $100 \%$ & Very good \\
\hline Statement 10 & 25 & $100 \%$ & Very good \\
\hline Average & & 100 & Very good
\end{tabular}

Based on the data in the table above, students can describe the statements items as follows:

1. The response of students who answered "yes" to statement number one is "learning media used by teachers is very interesting" based on data obtained $100 \%$ of students answered "Yes" from a total of 25 students. This condition is included in the very good category. From these data it can be concluded that all students agree that the media used by the teacher is very interesting.

2. Students' responses to statement number two namely "in this learning the teacher uses the media very well" based on data obtained by $100 \%$ of students answering "Yes" from a total of 25 students. This condition is included in the very good category. From these data it can be concluded that all students agree that in learning the teacher really uses the media well

3. Students' responses to statement number three namely "teachers do not use learning media optimally" based on data obtained by $100 \%$ of students answering "No" from a total of 25 students. This condition is included in the very good category. From these data it can be concluded that all students stated disagree with the teacher's statement not to use the learning media optimally. This means that teachers use learning media optimally.

4. Students' responses to statement number four namely "Learning media used by teachers are not interesting" based on the data obtained $100 \%$ of students answered "No" from a total of 25 students. This condition is included in the very good category. From these data it can be concluded that all students expressed disagreement that the instructional media used by the teacher were not attractive. This means that the media used by the teacher are interesting.

5. Students' responses to statement number five namely "I do not feel the benefits of learning media used by teachers" based on the data obtained $100 \%$ of respondents answered "No" from a total of 25 students. This condition is included in the very good category. From these data it can be concluded that all students expressed disagreement that students did not feel the benefits of the learning media used by the teacher. This means that students feel the benefits of the learning media used by teacher.

6. Students' responses to statement number six namely "I find it easier to understand lessons after the teacher uses the media in learning" based on the data obtained $100 \%$ of respondents answered "Yes" from a total of 25 students. This condition is included in the very good category. Based on these data it can be concluded that all students agree that students more easily understand the lesson after the teacher uses the media in learning.

7. Students' responses to statement number seven namely "I am more eager to follow the lessons when the teacher uses the media" based on the data obtained $100 \%$ of respondents answered "Yes" from a total of 25 students. This condition is included in the very good category. Based on these data it can be concluded that all students agree that students are more eager to follow the lesson when the teacher uses the media.

8. Students' responses to statement number eight namely "I am very happy to participate in learning using learning media used by teachers" based on data obtained $100 \%$ of students answered "Yes" from a total of 25 students. This condition is included in the very good category. From these data it can be concluded that all students agree that 
students are very happy to participate in learning using instructional media used by teacher.

9. Students' responses to statement number nine namely "Learning by using the media used by teachers, makes students able to bring up critical thinking skills" based on data obtained by $100 \%$ of students answering "Yes" from a total of 25 students. This condition is included in the very good category. From these data it can be concluded that all students agree that learning using the media used by the teacher, makes students able to bring up critical thinking skills.

10. Students' responses to statement number ten namely "students do not understand the material delivered by the teacher during the learning process" based on data obtained $100 \%$ of students answered "No" from a total of 25 students. This condition is included in the very good category. Based on these data it can be concluded that all students expressed disagreement that students did not understand the material delivered by teacher during teaching process. This means that all students understand the material delivered by teacher during teaching process.

\section{Discussion}

List 2. Criteria Analysis Percentage Descriptive

\begin{tabular}{c|c} 
Percentage & Criteria \\
\hline $75 \%-100 \%$ & Very good \\
\hline $50 \%-75 \%$ & Good \\
\hline $25 \%-50 \%$ & Less good \\
\hline $1 \%-25 \%$ & Not good
\end{tabular}

Based on premilinary study the analysis of questionnaire data, it can be seen that the average percentage of students' level of agreement and disapproval of the questionnaire influence the use of powtoon media in listening learning given to students by $100 \%$ with the criteria of interpretation of scores classified is very good, this proves that powtoon media can make Increase the students' knowledge about their material, and more actively in teaching learning process. According to (One, 2017) that the advantages of powtoon are more variety and motivated students in the teaching learning process.

The results of this study are in line with research conducted by (Yulia \& Ervinalisa, 2017) in a study entitled "The Effect Of Powtoon Learning Media in Indonesian History Lessons In Growing Learning Motivation of IIS Grade Tenth Students in 17 Batam State High School" using the method Quantitative research and the results of research show that there is a significant influence of using powtoon in teaching in Indonesian history learning development. This is evidenced by the results of the $t$ test which shows $t$ count (7.9) and t table at a significant level of $5 \%(1.922)$ it means $t$ count $>\mathrm{t}$ table (7.9>1.992) then $\mathrm{Ho}$ is refusal and $\mathrm{Ha}$ is acceptable.

\section{CONCLUSION}

Based on the research results obtained, all students choose the answer "Yes" which means agreeing to a positive statement and choosing the answer "No" which means not agreeing to a negative statement, with the total percentage of answers "Yes" on a positive statement reaching $600 \%$ and the percentage of answers "No" in negative statements reached $400 \%$. If the total is $600 \%+400 \%=1000 \%$ divided by the number of items of statement 10 so that an average result of $100 \%$ is obtained. Based on the descriptive percentage analysis criteria table, it can be 
concluded that the influence of the use of powtoon media is categorized very well in learning to listen at one of the junior high schools in cimahi $\left(8^{\text {th }}\right.$ grade).

\section{ACKNOWLEDGMENTS}

Praise and gratitude to God, for the blessing given to the researchers so that can complete this research. The researcher are thankful to the Lecturer Silpia Rahayu, S.Pd, M.Hum, who has guided in completing this research entitled "The Influence of Media Powtoon In Teaching Listening" as one of the requirements to get a degree in English education at IKIP Siliwangi Cimahi. The researcher hope this article could be helpful to reader or other researcher in the future.

\section{REFERENCES}

Günaydın, S., \& Karamete, A. (2016). Material development to raise awareness of using smart boards: an example design and development research.

Hadian, M. (2015). The Use of Song Lyrics in Teaching Listening. Journal of English and Education, 3(1), 96-105.

Nanni, A. (2015). Teaching English Through the Use of Cloud-Based Animation Software. The 35 Th Thailand TESOL, 1.

One. (2017). Efektivitas Penggunaan Media Pembelajaran Audiovisual Powtoon Dalam Meningkatkan Motivasi Belajar Siswa Di Madrasah Aliyah. Program Studi Pendidikan Ekonomi FKIP Pontianak, 1.1, 3.

Sugiyono, P. D. (2017). Metode Penelitian Bisnis: Pendekatan Kuantitatif, Kualitatif, Kombinasi, dan R\&D. Penerbit CV. Alfabeta: Bandung.

Suhara, A. . (2014). Implementasi Penilaian Sikap dalam Pembelajaran Bahasa Indonesia. Bandung: Program Studi Pendidikan Bahasa dan Sastra Indonesia STKIP Siliwangi Bandung. In Seminar Nasional Peran Bahasa, Sastra ....

Yulia, D \& Ervinalisa, N. (2017). Pengaruh Media Pembelajaran Powtoon Pada Mata Pelajaran Sejarah Indonesia Dalam Menumbuhkan Motivasi Belajar Siswa IIS Kelas X di SMA Negeri 17 Batam. Jurnal Program Studi Pendidikan Sejarah, 2 no.1, 15-24. 